\title{
GLOBAL MOTIVATIONS AND AQUACULTURE DEVELOPMENT TRENDS
}

\author{
Oleksandr Lukyanenko'
}

\begin{abstract}
The natural and geographical, resource, economic and environmental conditions, global motivations, key trends, specific features of formation and prospects for aquaculture development are researched. It is emphasized that fishing and aquaculture have a special place in solving the global food problem, while significantly affecting the aquatic environment. The interdisciplinary nature of scientific research in the conceptual format of fisheries economics, management of marine ecosystems, aquaculture, green and blue technologies are illustrated. The positioning of fisheries and aquaculture in the format of global problems of mankind and sustainable development in terms of environmentally irresponsible use of bioresources, especially the World Ocean is made, attention is focused on the potentially catastrophic consequences of its pollution, the problem of restoring fish stocks based on climate change is emphasized. The economic, ecological and social expediency of accelerated development of aquaculture, its institutional, functional and organizational-regulatory separation in the structure of global fisheries is substantiated, considering its complexity and inter-sectoral diversification, the author's model of aquaculture is proposed with classification identification of its categories (internal natural, artificial and combined reservoirs and marine, coastal and combined areas), types (with and without feed), species (bony fish, crustaceans, mollusks, other aquatic animals, algae), and consumer products (food, non-food, dual use). The scale, structure and dynamics of aquaculture development have been identified and assessed, and its growing importance in global fisheries has been confirmed. The analysis of the regional structure of aquaculture production by continents is carried out, its distribution by categories and species in Asia, North and South America, Europe, Africa and Oceania is characterized. The special leadership status of China in the global production of aquaculture products is illustrated. It is confirmed that aquaculture is becoming the main source of human fish consumption. The key trends in the development of aquaculture in the European Union have been identified and assessed. The special features of the formation of the relevant market are described. In addition, it has been demonstrated that the scale of aquaculture production only in Norway is comparable to the aggregate indicator of the EU countries. The volumes and structure of aquaculture financing from the budget of the European Maritime and Fisheries Fund are analyzed. Using Spearman's correlation ranks, the peculiarities of aquaculture consumption in terms of volume and price characteristics are studied. The conclusions of the research are substantiated, which confirm the hypothesis of perspective prospects of aquaculture advanced development using the modern innovative technologies and the effective system of its global regulation.
\end{abstract}

Key words: global problems of mankind, sustainable development, global aquasystem, aquatic bioresources, fisheries, aquaculture.

JEL Classification: F01, F06, Q01, Q22, Q25

\section{Introduction}

Significant population growth, climate change and pollution of the World ocean, the food crisis in developing countries, the active development of recreation on the coast of reservoirs, inefficiently controlled poaching have led to reduced fishing productivity, reduced water resources. Global fisheries and aquaculture, being not only particularly significant in terms of humanity's virtually inexhaustible food resources, but also extremely sensitive to the natural environment and human health, are becoming a relevant subject of scientific research. Researchers, in particular WS Mackenzie (Mackenzie, 1992), emphasize the crucial importance of sectoral analysis in fisheries, although today, global fisheries research is quite diversified within fundamental areas: managing climate change research and its impact on fisheries

Corresponding author:

${ }^{1}$ Kyiv National Economic University named after Vadym Hetman, Ukraine.

E-mail: lukyanenko.a.d@gmail.com 
(Barange, Bahri, 2018); fishery management and waste management models (Toppe, Olsen, 2018); monitoring of marine ecosystem management (Juan-Jorda, Murua, 2018; Sindair, Valdimarsson, 2003); management of green technologies (Alkawili, Pateiro, 2019). In general, the study of the fisheries and aquaculture system is interdisciplinary. With this in mind, S. Pascoe draws attention to the growing role of economics in the management of the marine environment combined with the use of the benefits of economic analysis (Pascoe, 2006). To some extent, he is supported by L. Anderson, who carefully substantiates his point of view on the methodology of the fish economy, its structural basis and methods of studying the movement of goods and money in this extremely complex and sometimes confusing area of reproduction and consumption (Anderson, 2002). The most complete analysis of the state of world fisheries and aquaculture is provided annually by FAO, identifying not only the main trends, but also the problems and current priorities (Rome: FAO, 2020) with some conflicting international and national statistics.

At the same time, in the conditions of superdynamic globalization with acceleration of new opportunities and challenges, certain aspects of the researched problems are insufficiently revealed and substantiated. This concerns first of all the scientific substantiation of the necessity and expediency of institutional, functional, organizational and regulatory separation in fisheries along with natural industry - aquaculture, based on technologies of artificial cultivation of almost all types of aquatic bioresources in inland, coastal and marine (mariculture) reservoirs, appropriate food and non-food products, while preserving the biodiversity of commercialized aquasystems.

The purpose of the article is a comprehensive study of the features, motivations and trends of aquaculture in the structure of global fisheries. Research tasks are focused on:

- identification of multifunctional specifics and interdisciplinary essence of global fisheries and aquaculture;

- positioning of fisheries in the format of problems and tasks of sustainable development;

- identification of aquaculture and its systematization by categories, types, species and consumer forms;

- identification and assessment of global and regional trends in aquaculture.
In methodological terms, it was important to confirm the hypothesis of compliance of the advanced development of aquaculture with the concepts of "blue" growth and the circular economy in the paradigm line of sustainable development.

\section{Fisheries and aquaculture in the concept of sustainable development}

Progress in the field of world fisheries and aquaculture, the formation of environmentally and socio-oriented and responsible management in the fishing industry is an extremely important and important task in improving its efficiency by intensifying productive and mutually beneficial multilevel international cooperation. Trade, investment and innovation cooperation, as well as in solving the global food problem on the principles of sustainability generally recognized and implemented in international national legislation.

In the format of the global problems of humanity of the XXI century, food resources and development of the World Ocean and related problems of population growth, ecology and human health occupy prominent places along with social inequality and poverty, informatization, conflict and security of development.

According to experts: the use of natural bioresources has more than tripled since 1970 and continues to grow; modern models of natural resource use increase the negative impact on the environment and human health; in the absence of immediate coordinated action, the rapid growth of inefficient use of natural resources becomes incompatible with sustainable development (Oberle, Bringezu, Khetfield-Dodds, Khellveg, Khaynts Shandl, Klement, 2019). This fully applies to the group of renewable and non-renewable hydrosphere resources (glaciers, oceanic, marine, lakes, rivers, reservoirs) and the corresponding biosphere.

Contamination of the World Ocean with mineral fertilizers, pesticides, plastics, radioactive waste, and the consequences of man-made disasters is gaining potentially catastrophic proportions. The problem of restoring fish stocks of the World Ocean is also acute. According to FAO estimates, in $2017,34.2 \%$ of the World Ocean fish stocks were exploited by overfishing. At the same time, overfishing (reduction of the number of stocks due to their catch to volumes below the level capable of ensuring maximum sustainable production) 
not only negatively affects biodiversity, but also provokes a reduction in catches, which leads to negative socio-economic consequences. It takes not only a long time to stop it, but also strong political will, especially at the national level; building institutional and managerial capacity, technology transfer and capacity building for the use of scientifically sound advanced management methods; control over industrial capacities and intensity of catch in volumes which do not reduce productivity of resources; changes in consumer perception through market mechanisms and educational activities; improving the global monitoring system to help provide the public with transparent and timely information (Rim: FAO, 2020).

The important factor in the global impact on the modern fisheries market is climate change, which leads to the destruction of traditional fish migration and, consequently, the death of some marine animals, because the food chain of many creatures in the hydrosphere has been broken and disoriented, and, thus, the chances of full recovery are reduced.

It should be noted that among the globally institutionalized seventeen sustainable development goals (RIO, 2012), the twelfth position is "Providing conditions for sustainable consumption and production", and the fourteenth - "sustainable consumption of ocean and sea resources" The main criteria for sustainability of fisheries and aquaculture implementation of sound policy in the field of management of this sector, predictable and transparent regimes for the use of fish in international markets, the achievement of which is regulated by the Code of Conduct for Responsible Fisheries, adopted by the Governments of 170 FAO member countries in 1995 (Rim: FAO, 2020).

Taking into account global trends, challenges and threats (climate change, man-made pollution of the environment, intensity of industrial and poaching of rare species of aquatic bioresources, the most productive model of aquaculture in the global fisheries management system becomes important. in aquaculture in the paradigm of sustainable development.

\section{Aquaculture in global fisheries}

Limited and uneven distribution of natural fish resources, given the rapid growth of the planet's population, increasing the affordability of fisheries products due to technological progress have deepened existing and new contradictions, especially between catches of fish and seafood and growing consumption. In this regard, special attention needs to be paid to the development of aquaculture, which has gradually been integrated not only into global fisheries, but also into natural and economic, social and cultural-mental environment.

Nowadays aquaculture is a complex and highly structured system of regulated at the national, regional and global levels of fisheries (Figure 1).

The share of aquaculture in 2018 accounted for $46.0 \%$ of all fish supplied to world markets, which is $25.7 \%$ more than in 2000 ; the total volume excluding China was $29.7 \%$ compared to $12.7 \%$ in 2000. At the regional level, aquaculture accounted for $17.9 \%$ of total fish production in Africa, $17 \%$ in Europe, and $17 \%$ in North and South America. $15.7 \%$, and in Oceania $-12.7 \%$. The share of the sector in total fish production in Asia has increased (excluding China): if in 2000 it was $19.3 \%$, in $2018-42.0 \%$ (Rome: FAO, 2020).

According to aquaculture data from world statistics published by FAO, the volume of aquaculture production in the world in 2018 rose again to a record level $-114.5 \mathrm{mln}$ tons in live weight, which in initial sales prices amounted to 263.6 bln dollars. USA. Total production consisted of $82.1 \mathrm{mln}$ tons of aquatic animals ( $\$ 250.1 \mathrm{bln})$, $32.4 \mathrm{mln}$ tons of algae ( $\$ 13.3 \mathrm{bln})$ and 26,000 tons of decorative shells and pearls (179,000 USD).

Characteristics of categories and species of aquaculture by regions of the world are presented in the Table 1.

The undisputed global leader in the production of aquaculture products is China $-47,560,000$ tons of live weight. (Rome: FAO, 2020).

In a relatively short time, aquaculture becomes the main source of human consumption of fish. At the same time, in 1950 its production was only $4 \%$, in $1980-9 \%$, and in $1990-19 \%$ in the diet, and in 2018 it accounted for 52\%. It is important to note that the dominance of aquaculture products in world fish markets significantly changes the patterns of sales and consumption of fish. In fish farming, production processes are controlled more carefully than in industrial fish farming, and conditions are created for vertical and horizontal integration of supply chains (Rim: FAO, 2020).

In line with a key global trend in fisheries development, two types of markets have been created and are functioning in the EU: traditional 


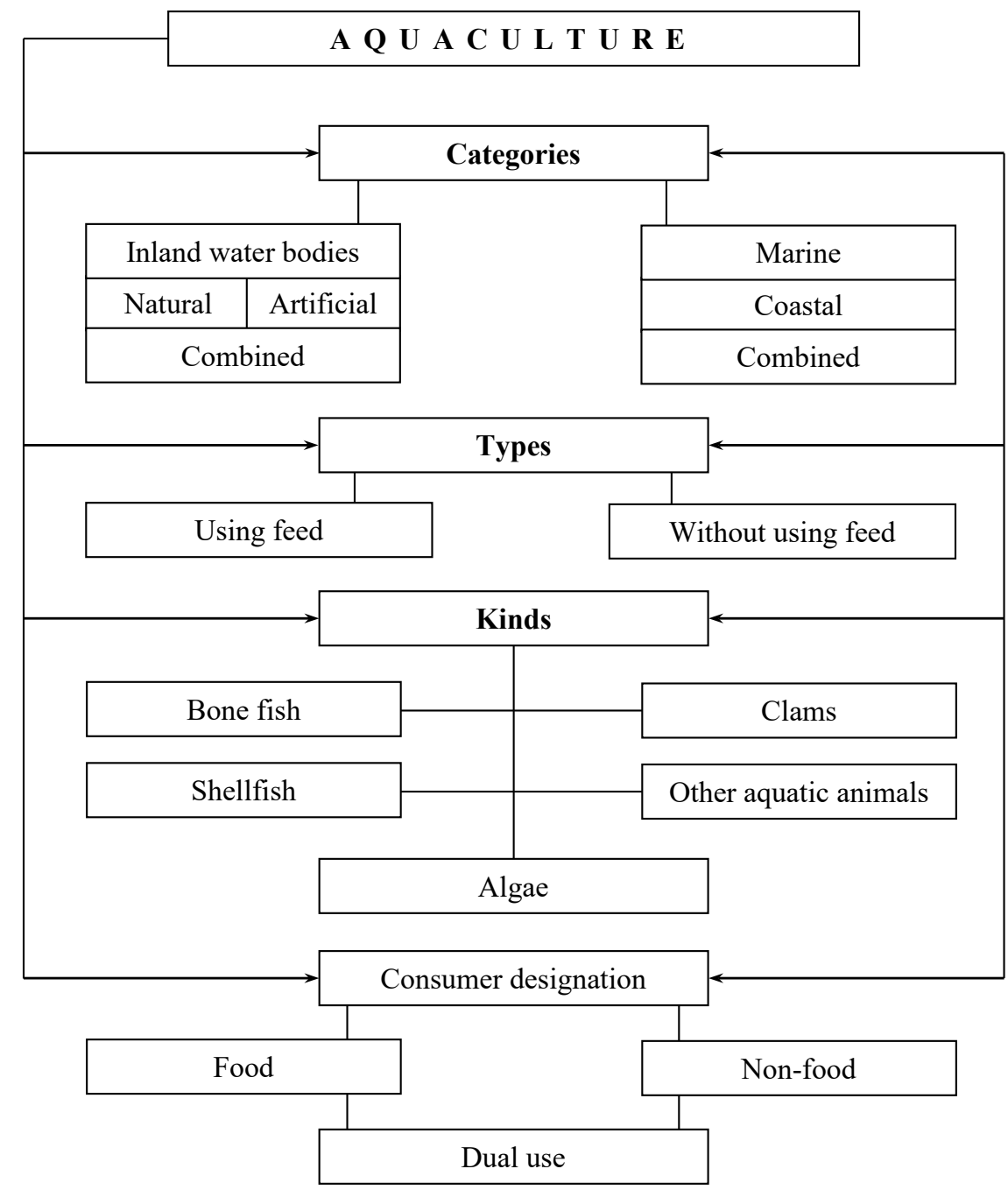

Figure 1. Classification model of aquaculture

Source: developed by the author

(wild fish and seafood, which have always been considered extremely valuable) and those bred in artificial reservoirs (aquaculture), powerful industrialization and introduction of the newest resource-saving technologies. Moreover, in the presence of the infrastructure of industrial aquaculture, each of the EU countries has the opportunity to vary between: a) what is caught in the seas; b) is reflected in export-import operations; c) identified in inland waters. Taken together, these market segments determined the relative constancy of demand, total and per capita consumption and the corresponding price level of fish products.

In general, the development of aquaculture in the European region is characterized by a steady positive trend. At the same time, FAO's data on the contribution of the European Union member states to this progressive segment of the fishing industry are quite indicative. Today, the scale of aquaculture in Norway alone is comparable to that of the EU as a whole, which in turn accounts for up to $2 \%$ of the world (Rome: FAO, 2020).

Under Sustainable Aquaculture ( $€ 1.1$ billion, or $17.7 \%$ of the European Maritime and Fisheries Fund budget), funding is aimed at maintaining the competitiveness, quality, safety and environmental friendliness of the European fisheries sector. Tools to increase the competitiveness of fisheries may include, in particular, aid to start fishing for fishermen under the age of 40 who have at least five years of professional experience in the sector (up to $€ 75,000$ ) to invest in vessels up to $12 \mathrm{~m}$; investments in modernization of fishing vessels and replacement of engines in order to reduce their power and $\mathrm{CO}_{2}$ emissions; support for innovation (development of environmentally friendly vessels), as well as investment in port infrastructure 
Table 1

Aquaculture production of the main groups of species broken down by category, species and continent, 2018 (Rim: FAO, 2020)

\begin{tabular}{|c|c|c|c|c|c|c|}
\hline Category & Africa & $\begin{array}{c}\text { North } \\
\text { and South } \\
\text { America }\end{array}$ & $\begin{array}{c}\text { Asia } \\
\text { (without } \\
\text { Cyprus) }\end{array}$ & $\begin{array}{c}\text { Europe } \\
\text { (including } \\
\text { Cyprus) }\end{array}$ & Oceania & $\begin{array}{c}\text { The whole } \\
\text { world }\end{array}$ \\
\hline \multicolumn{7}{|c|}{ Aquaculture on inland waters } \\
\hline 1. Bone fish & 1893 & 1139 & 43406 & 508 & 5 & 46951 \\
\hline 2. Crustaceans & 0 & 73 & 3579 & 0 & 0 & 3653 \\
\hline 3. Mollusks & $\ldots$ & $\ldots$ & 207 & $\ldots$ & $\ldots$ & 207 \\
\hline 4. Other aquatic animals & $\ldots$ & 1 & 528 & 0 & $\ldots$ & 528 \\
\hline Interim result & 1893 & 1213 & 47719 & 508 & 6 & 51339 \\
\hline \multicolumn{7}{|c|}{ Marine and coastal aquaculture } \\
\hline 1. Bone fish & 291 & 1059 & 3995 & 1892 & 92 & 7328 \\
\hline 2. Crustaceans & 6 & 888 & 4834 & 0 & 6 & 5734 \\
\hline 3. Mollusks & 6 & 640 & 15876 & 680 & 102 & 17304 \\
\hline 4. Other aquatic animals & 0 & $\ldots$ & 387 & 3 & 0 & 390 \\
\hline Interim result & 302 & 2587 & 25093 & 2575 & 200 & 30756 \\
\hline \multicolumn{7}{|l|}{ Aquaculture, total } \\
\hline 1. Bone fish & 2184 & 2197 & 47400 & 2399 & 97 & 54279 \\
\hline 2. Crustaceans & 6 & 961 & 8414 & 0 & 6 & 9387 \\
\hline 3. Mollusks & 6 & 640 & 16083 & 680 & 102 & 17511 \\
\hline 4. Other aquatic animals & 0 & 1 & 915 & 3 & 0 & 919 \\
\hline Total & 2196 & 3799 & 72812 & 3083 & 205 & 82095 \\
\hline
\end{tabular}

Note: $0=$ production volume does not reach 500 tons ... = production is not conducted, or production data are missing.

(EMFF, 2018; Fisheries structural assistance: Fact Sheets on the European Union, 2018).

Organic fisheries and aquaculture products are a special and highly dynamic niche in the EU market. According to Eurostat, the total production of organic aquatic organisms in the EU in 2018 amounted to 69 thousand tons. In the leading EU countries studied - Germany, Spain, France, Italy and the United Kingdom 46.5 thousand tons of raw fishery and aquaculture products consumed in 2019 were obtained from organic production, which is $20 \%$ more than in 2015 (The EU fish market, 2020). The leading consumers of organic fish products in the EU in absolute terms are the United Kingdom and Germany, but in all countries surveyed, 2019 was a record year for organic consumption in the last five years. Thus, compared to 2015, the most significant growth of $48 \%$ was recorded in France, while in Germany - by $21 \%$, in Italy - by $18 \%$, in Spain - by $15 \%$, in the UK - by $13 \%$.

In general, today clearly define the nature of the European fish market. Its trends and structure can only be explored by the peculiarities of consumption of aquaculture products, which can be identified both at the level of cash receipts and total catches (volumes) using Spearman's correlation ranks (R) (Table 2).

$$
R=1-6 \frac{\sum \mathrm{d}^{2}}{\mathrm{n}\left(\mathrm{n}^{2}-1\right)}
$$

where $\mathrm{n}$ - quantity of ranked features (27 EU countries);

$\mathrm{d}$ - difference between the ranks;

$\mathrm{d}^{2}-$ sum of squares.

Substituting the numerical values in Spearman's formula we obtain:

$$
R=1-6 \frac{216}{27(729-1)}=0,934 \text {. }
$$

The calculations show that there is a fairly close relationship between the amount of money received for fish and seafood and the amount caught. That is, aqua companies in a regulated EU market act as a kind of simulator of fluctuations in prices and volumes of fish and seafood supplied to the European market. Calculations have shown that the closeness of the links $(x, y)$ is extremely high, which makes fluctuations in the catch mechanism (harvesting) effective to maintain stable prices for these products.

It is quite significant that in the share of food fish products (processed) in the structure 
Vol. 1, No. 2, 2020

Table 2

Research of correlation between the total price $(x)$ and volumes $(y)$ of aquaculture production in the EU (2017)

\begin{tabular}{|c|c|c|c|c|}
\hline Country & $\mathrm{x}$ & $\mathrm{y}$ & $(x-y)$ & $(x-y)^{2}$ \\
\hline Great Britain & 1 & 2 & 1 & 1 \\
\hline France & 2 & 3 & 1 & 1 \\
\hline Spain & 3 & 1 & 2 & 4 \\
\hline Greece & 4 & 5 & 1 & 1 \\
\hline Italy & 5 & 4 & 1 & 1 \\
\hline Ireland & 6 & 7 & 1 & 1 \\
\hline Malta & 7 & 14 & 7 & 49 \\
\hline Denmark & 8 & 9 & 1 & 1 \\
\hline Poland & 9 & 8 & 1 & 1 \\
\hline Croatia & 10 & 13 & 3 & 9 \\
\hline Germany & 11 & 10 & 1 & 1 \\
\hline Netherlands & 12 & 6 & 6 & 36 \\
\hline Portugal & 13 & 19 & 6 & 36 \\
\hline Finland & 14 & 17 & 3 & 9 \\
\hline Czech Republic & 15 & 11 & 4 & 16 \\
\hline Sweden & 16 & 16 & 0 & 0 \\
\hline Hungary & 17 & 12 & 5 & 25 \\
\hline Cyprus & 18 & 20 & 2 & 4 \\
\hline Bulgaria & 19 & 15 & 4 & 16 \\
\hline Romania & 20 & 18 & 2 & 4 \\
\hline Austria & 21 & 21 & 0 & 0 \\
\hline Lithuania & 22 & 22 & 0 & 0 \\
\hline Slovakia & 23 & 23 & 0 & 0 \\
\hline Slovenia & 24 & 24 & 0 & 0 \\
\hline Estonia & 25 & 25 & 0 & 0 \\
\hline Latvia & 26 & 26 & 0 & 0 \\
\hline Belgium & 27 & 27 & 0 & 0 \\
\hline Total, EU - 28 & - & - & $\Sigma$ & 216 \\
\hline
\end{tabular}

* - without Luxembourg

of gross value added is $2.1 \%$ ), and among the employed - according to X.Gellynck, W.Verbeke, J.Viaene - 3.3 \% (Gellynck, Verbeke, Viaene, 2003). These figures remain virtually unchanged for a fairly long period of time (since 1997). However, it is too early to talk about the completed conglomeration of the EU fisheries market, as a kind of ranking contrast in terms of $\mathrm{x}$ and $\mathrm{y}$ still remains quite significant for countries such as Malta, the Netherlands, Portugal and some others, where aggregate aquaculture consumption external factors, but also a number of internal (consumption culture, traditions, cooking preferences, etc.). Equally important is the fact that in artificial reservoirs and in some parts of the sea are trying to breed expensive fish species (salmon, trout), rather than those that do not involve significant investment costs (herring).

\section{Conclusions}

1. In view of global problems of mankind of the XXI century, caused by climatic, technological, economic and political factors with unequal distribution of resources and population, food supply and development of the World Ocean and related problems of ecology and human health are the most important.

2. The formation and development of global fisheries reflects, on the one hand, its multifunctional nature, natural-geographical, infrastructural-logistical and consumer specifics, and, on the other hand, determines the diversification of research approaches with emphasis on the impact of climate change. Monitoring of ecosystems, 
waste-free technologies of "blue growth" in the paradigm of sustainable development.

3. Given the growing demand and supply of aquatic bioresources, the impact of fisheries on the global ecosystem is an extremely important scientific and practically significant task is the systematic determination of criteria and parameters of aquaculture, assessment of its available and promising resources, scale and rate of extraction and recovery. The model of aquaculture as a system includes resource, technical production and technological base. Multilevel regulation, monitoring and forecasting in interrelated segments of the fisheries economy, seas and oceans economy, bioeconomy. blue and circular economies.

4. In the interdisciplinary field of research on the advanced development of aquaculture, the problems of organizing effective business remain powerful at the macro level as powerful multinational corporations, regional clusters or resource centers, and local small and medium business associations, fishing cooperatives, joint ventures, and at the macro level - tools regulation and monitoring of economic results of this type of enterprise, de-shadowing of poaching incomes, tax optimization.

5. The special attention shall be paid to the technological progress in aquaculture, the use of sensors for collecting optical (using cameras) and physical data on fish farming and health, optimization of feed regimes, etc.; use of DNA technologies for fish breeding; use of blockchain for traceability, accuracy and accountability at all stages of production and marketing chains in the fishing industry.

6. The global problem of the COVID-19 pandemic needs thorough analysis and unbiased forecasting, as many aquaculture farms in the EU, Asia and the United States will not be able to survive the economic crisis. The prolongation of the pandemic and its consequences for global aquaculture will be much larger, due to the expected general economic crisis, which will be systemic in nature, affecting the interests of small and large businesses. social sphere. Financing of state and international aquaculture and environmental programs.

\section{References:}

Vodnyj kodeks Ukrajiny. Retrieved from: https://zakon.rada.gov.ua/laws/show/213/95-\%D0\% B2\%D1\%80\#Text

Oberle, B., Bringezu, S., Khetfild-Dodds, S., Khellveg S., Khaynts Shandl, K., \& Klement, D. (2019). Prognoznaya otsenka mirovogo resursnogo potentsiala 2019. Retrieved from: http://www.wedocs.unep.org/ handle/GRO_2019_SPM_RU

Sostoyanie mirovogo rybolovstva i akvakul'tury. Mery po povysheniyu ustoychivosti 2020. - Rim: Prodovol'stvennaya i sel'skokhozyaystvennaya Organizatsiya Ob'edinennykh Natsiy. - Rim: FAO. 2020. 207 p. Retrieved from: http://www.fao.org/3/ca9229ru/CA9229RU.pdf

Al Khawli, F., Pateiro, M., Dominguez, R., Lorenzo, J. M., Gullón, P., Kousoulaki, K., Ferrer, E., Berrada, H., \& Barda, F. J. (2019). Innovative green technologies of intensification for valorization of seafood and their by-products. Marine Drugs, 17:689 [online]. [Cited 18 March 2020]. Retrieved from: www.mdpi.com/1660-3397/17/12/689/html

Anderson, L. (2002). Fisheries Economics. Vol. 1. Routledge.

Barange, M., Bahri, T., Beveridge, M. C. M., Cochrane, K. L., Funge-Smith, S., \& Poulain, F., eds. (2018). Impacts of climate change on fisheries and aquaculture: synthesis of current knowledge, adaptation and mitigation options. FAO Fisheries and Aquaculture Technical Paper No. 627. Rome, FAO. 628 p. Retrieved from: www.fao.org/3/i9705en/i9705en.pdf

European Maritime and Fisheries Fund (EMFF) / European Commission. Retrieved from: https://ec.europa.eu/fisheries/cfp/emff_en

Fisheries structural assistance: Fact Sheets on the European Union. Retrieved from: https://www.europarl.europa.eu/factsheets/en/sheet/117/fisheries-structural-assistance

Gellynck, X., Verbeke, W., \& Viaene, J. (2003). Food processing. Industries in Europe. Competition, Trends and Policy Issues / Ed. By Peter Johnson. Cheltenham: Edward Elgar, $426 \mathrm{p}$.

Juan-Jordá, M. J., Murua, H., Arrizabalaga, H., Dulvy, N. K., \& Restrepo, V. (2018). Report card on ecosystem-based fisheries management in tuna regional fisheries management organizations. Fish and Fisheries, 19(2): 321-339.

Mackenzie, W. C. (1992). An introduction to the economics of fisheries management. Retrieved from: www.Fao.org/3/T0506E/T0506EDOhtm\#Toc/ 
Pascoe, S. (2006). Economics, fisheries, and marine environment. ISES, journal of marine science. 63: 1-3. Sinclair, M., \& Valdimarsson, G. (2003). Responsible fisheries in the marine ecosystem. Wallingford, UK, $\mathrm{CAB}$ International, $448 \mathrm{p}$.

The EU fish market. 2020 Edition / EUMOFA, Directorate-General for Maritime Affairs and Fisheries. Luxembourg: Publications Office of the European Union, 2020. $101 \mathrm{p}$.

Toppe, J., Olsen, R. L., Reňarubia, O. R., \& James, D. G. (2018). Production and utilization of fish silage. A manual on how to turn fish waste into profit and a valuable feed ingredient or fertilizer. Rome, FAO. 30 p. Retrieved from: www.fao.org/documents/card/en/c/19606EN 